\title{
Review
}

\section{The GSK3-NRF2 Axis in Suicide}

\author{
Hans O. Kalkman ${ }^{\dagger}$
}

check for

updates

Citation: Kalkman, H.O. The GSK3-NRF2 Axis in Suicide.

Psychiatry Int. 2021, 2, 108-119.

https://doi.org/10.3390/

psychiatryint 2010008

Received: 15 February 2021

Accepted: 19 March 2021

Published: 21 March 2021

Publisher's Note: MDPI stays neutral with regard to jurisdictional claims in published maps and institutional affiliations.
Gänsbühlgartenweg 7, CH-4132 Muttenz, Switzerland; hans.kalkman@bluewin.ch; Tel.: +41-61-362-0110

† Retired Pharmacologist.

\begin{abstract}
Mutations in the genes coding for tryptophan-hydrolase-2 and the scaffold protein FKBP5 are associated with an increased risk of suicide. The mutation in both cases enhances the enzymatic activity of glycogen synthase kinase-3 (GSK3). Conversely, anti-suicidal medications, such as lithium, clozapine, and ketamine, indirectly inhibit the activity of GSK3. When GSK3 is active, it promotes the metabolic removal of the transcription factor NRF2 (nuclear factor erythroid 2-related factor-2), which suppresses the transcription of multiple genes that encode anti-oxidative and antiinflammatory proteins. Notably, several suicide-biomarkers bear witness to an ongoing inflammatory process. Moreover, alterations in serum lipid levels measured in suicidal individuals are mirrored by data obtained in mice with genetic deletion of the NRF2 gene. Inflammation is presumably causally related to both dysphoria and anger, two factors relevant for suicide ideation and attempt. Preventing the catabolism of NRF2 could be a strategy to obtain novel suicide-prophylactic medications. Possible candidates are minocycline and nicotinic- $\alpha 7$ agonists. The antibiotic minocycline indirectly activates NRF2-transcriptional activity, whereas the activation of nicotinic- $\alpha 7$ receptors indirectly inhibits GSK3.
\end{abstract}

Keywords: suicide pathophysiology; GSK3; NRF2; ketamine; minocycline; nicotinic- $\alpha 7$ receptor; clozapine; biomarker; lipid profile

\section{Introduction}

Around the globe, suicide is a major health concern and a prevalent cause of death in young adults (for recent summary see [1]). Predicting suicide is a difficult task [2-4]. Compounds with prophylactic activity such as ketamine, lithium or clozapine are fraught with adverse effects and can only be used in the context of major depressive disorder (MDD), bipolar disorder and schizophrenia, respectively [5-7]. A better understanding of the underlying pathology, more reliable biomarkers, as well as better-tolerated medications are urgently needed. The current review focusses on the role of the transcription factor $\mathrm{NRF} 2{ }^{*}$ in suicide and how it is modulation by the kinase GSK3. A list of acronyms is provided at the end of this article.

\section{NRF2 Overview}

NRF2 activates transcription of genes that encode proteins involved in antioxidant defense and anti-inflammatory activity (for recent reviews see [8-10]). Several genes that encode proteins involved in the regulation of autophagy, mitochondrial function, and clearance of damaged proteins are also NRF2 targets (reviewed by [9-12]). Examples of NRF2-activated anti-inflammatory genes are, interleukin-10 (IL10), interleukin-1 receptor antagonist (IL1-RA), suppressor of cytokine signaling-3 (SOCS3), brain-derived neurotrophic factor (BDNF), B-cell lymphoma-2 (BCL2), and B-cell lymphoma extra-large $\left(B C L_{X L}\right)$ [13-15]. Mice with a genetic deletion of NRF2 display increased expression of cyclooxygenase-2 (COX2), inducible nitric-oxide synthase (iNOS), pro-inflammatory cytokines like IL- 6 and tumor necrosis factor- $\alpha(\mathrm{TNF} \alpha)$, and produce more reactive oxygen species, but are deficient in BDNF, IL-10, SOCS3, or BCL XL $[10,13,16]$. Under resting conditions, the biological half-life of NRF2 is just $20 \mathrm{~min}[8,12]$. The stability of NRF2 in the 
cytosol is determined by two mechanisms. One mechanism involves a destruction-complex consisting of the adaptor molecule KEAP1, and the E3-ligase CUL3/RBX1. KEAP1 is a redox- and electrophile sensor, that upon modification of critical cysteine-residues, loses its ability promote NRF2-ubiquitination by CUL3/RBX1 [10]. The alternative mechanism for degradation of NRF2 involves GSK3-meditated phosphorylation of NRF2. In this process a recognition site for an alternative ligase adaptor $\beta$-TrCP is created, which again allows ubiquitination of NRF2, in this case by CUL1/ $\beta-\operatorname{TrCP}[17,18]$. Subsequently, ubiquitinatedNRF2 is degraded by the proteasome [10]. The anti-inflammatory activity of NRF2 is thought to result from at least three distinct mechanism, including modulation of redox mechanisms, competition of NFKB subunit p65 and direct suppression of the transcription of pro-inflammatory cytokines, including IL-6 [12,19,20]. Hypoactivity of NRF2 has been proposed to occur in many neurodegenerative- [11] and mood disorders [16]. Hypoactivity of NRF2 can be prevented by inhibition of KEAP1 or via inhibition of GSK3.

\section{Suicide Overview}

Suicide seems to be a two-stage process [21-24]. Suicidal ideation is association with an inflammatory process, whereas the suicidal attempt is associated with symptoms of irritability, hypervigilance and aggression [25]. In agreement with this notion, increased suicide numbers have been reported in individuals with ADHD [22], conduct disorder [25], substance abuse [25,26], PTSD [25,27,28], and bipolar disorder [29]. Moreover, treatment of juveniles with antidepressants can trigger aggressive behavior and akathisia, and this presumably is the reason for the elevated risk of suicide [30]. The inflammatory state is frequently independent of depression [31-37]. The inflammatory processes that are documented in suicide can be attributed to mechanisms like neurotropic pathogens, life-long stressors, allergies, autoimmunity, or traumatic brain injury (see Table 1). Peripheral levels of CRP and both peripheral and central levels of IL-6 are dose-dependently associated with suicide risk and with the choice of more a violent method (Table 1 ; [36]). Inflammatory cytokines (IL-1 $\beta$, IL-6) are potent inducers of IDO1 and can explain the increase in kynurenine pathway metabolites [34,38]. In particular, CSF levels of IL-6 correlated with CSF levels of the kynurenine-metabolite quinolinic acid (reviewed in [38]). GSK3 inhibitors are effective anti-inflammatory drugs and reduce the production of IL- 6 , TNF $\alpha$, and IL- $1 \beta$ by microglia, astrocytes, monocytes, and PBMCs by 70-90\% [39].

Table 1. List of inflammatory disorders and biomarkers associated with suicide.

\begin{tabular}{cc}
\hline Inflammatory Process & Citation for Role in Suicide \\
\hline $\begin{array}{c}\text { Hospitalization for infection (HIV, hepatitis, respiratory } \\
\text { tract, sepsis) }\end{array}$ & {$[40]$} \\
\hline Seropositivity to Toxoplasma gondii & {$[41-43]$} \\
\hline Physical and sexual abuse & {$[22]$} \\
\hline Life time headache & {$[44]$} \\
\hline Allergy to tree- and grass pollen & {$[45,46]$} \\
\hline Asthma & {$[47]$} \\
\hline Brain IL-4 and IL-13 mRNA & {$[48]$} \\
\hline Lung disease, cancer, chronic pain & {$[33,49]$} \\
\hline Coronary artery disease, osteoporosis & {$[33]$} \\
\hline Somatic disorders & {$[50]$} \\
\hline Extreme obesity & {$[51]$} \\
\hline
\end{tabular}


Table 1. Cont.

\begin{tabular}{cc}
\hline Stroke & {$[52]$} \\
\hline Concussion & {$[53]$} \\
\hline Rheumatoid arthritis & {$[54]$} \\
\hline IFN $\beta$ treatment in multiple sclerosis & {$[55]$} \\
\hline IL-6 in CSF and serum (dose-dependent) & {$[35,56-58]$} \\
\hline Elevated Kynurenine and Quinolinic acid in plasma and CSF & {$[34,59-61]$} \\
\hline CRP levels in MDD (dose-dependent) & {$[62,63]$} \\
\hline High SAT1 mRNA in brain and PBMCs & {$[64,65]$} \\
\hline Juxtavascular microglia activation (IBA1) & {$[31,66]$} \\
\hline High serum S100 $\beta$ & {$[32]$} \\
\hline High white blood cell count & {$[67]$} \\
\hline Lipid abnormalities (low total-cholesterol, low LDL, low HDL) & {$[68-70]$} \\
\hline
\end{tabular}

CRP: C-reactive protein; CSF: cerebrospinal fluid; IBA1: ionized calcium binding adaptor molecule-1; HDL: high-density lipoprotein; IFN $\beta$ : interferon- $\beta$; LDL: low-density lipoprotein; MDD: major depressive disorder; PBMC: peripheral blood mononuclear cells; SAT1: spermidine/spermine N1-acetyltransferase-1.

\section{GSK3 Activity in Suicide}

Genetic evidence exists that GSK3 activity is involved in suicide. In patients suffering from HIV infection, depression was associated to high levels of FKBP5 (mRNA, protein) in the frontal cortex [71]. SNPs in FKBP5 that increase intracellular protein levels are associated with recurrence of depressive episodes. An over-representation of high-induction alleles has been found in the STAR ${ }^{*} \mathrm{D}$ study in MDD [72] and in bipolar disorder [73]. Notably, SNPs in FKBP5 are also associated with attempted and completed suicide [74-77]. In the brain, FKBP5 acts as scaffold for the interaction of the kinase Akt/PKB and the phosphatase PHLPP1 $\alpha$. Facilitated phosphatase-activity leads to a reduction in Ser472-phosphorylation of Akt/PKB and in Ser567-phosphorylation of PKC $\alpha$ [78-80]. The high-induction allele of FKBP5 is therefore expected to reduce phosphorylation of Akt/PKB and PKC. This, in turn, limits kinase activity of Akt/PKB and PKC and results in activation of GKS3. This is consistent with the observation of decreased catalytic activity of Akt/PKB $[81,82]$ and PKC [83] in suicide victims, and the reduced levels of (inhibitory) Serine 9-phosphorylation of GSK3 $\beta[82,84]$.

Mutations in the TPH2 gene that affect transcription, mRNA stability or enzyme activity are associated with suicide [85-91]. One of the human variants of TPH2 has been expressed in mice. This variant reduced brain 5-HT production by $80 \%$ [92]. Importantly, GSK3 activity in these mice was increased, while the animals displayed anxious and depression-like behaviors that were normalized by inhibition of GSK3 [92].

\section{Therapeutic Effect of GSK3 Inhibition}

At therapeutic concentrations, lithium prevents the dephosphorylation (deactivation) of Akt/PKB and therefore indirectly inhibits GSK3 [93-95]. Chronic treatment with relevant concentrations of lithium increased nuclear levels of NRF2 in PC12 and N2A cells, and increased NRF2-transcriptional activity [96-98]. Knock-down of NRF2 inhibited lithium-increased expression of NRF2 and suppressed the protective effect of lithium against $\mathrm{H}_{2} \mathrm{O}_{2}$ [98]. Thus, there is direct evidence that lithium stimulates the transcriptional activity of NRF2. Lithium is one of the very few medications with proven efficacy in the prevention of suicide [6]. A schematic overview of the signaling cascade is provided in Figure 1. 


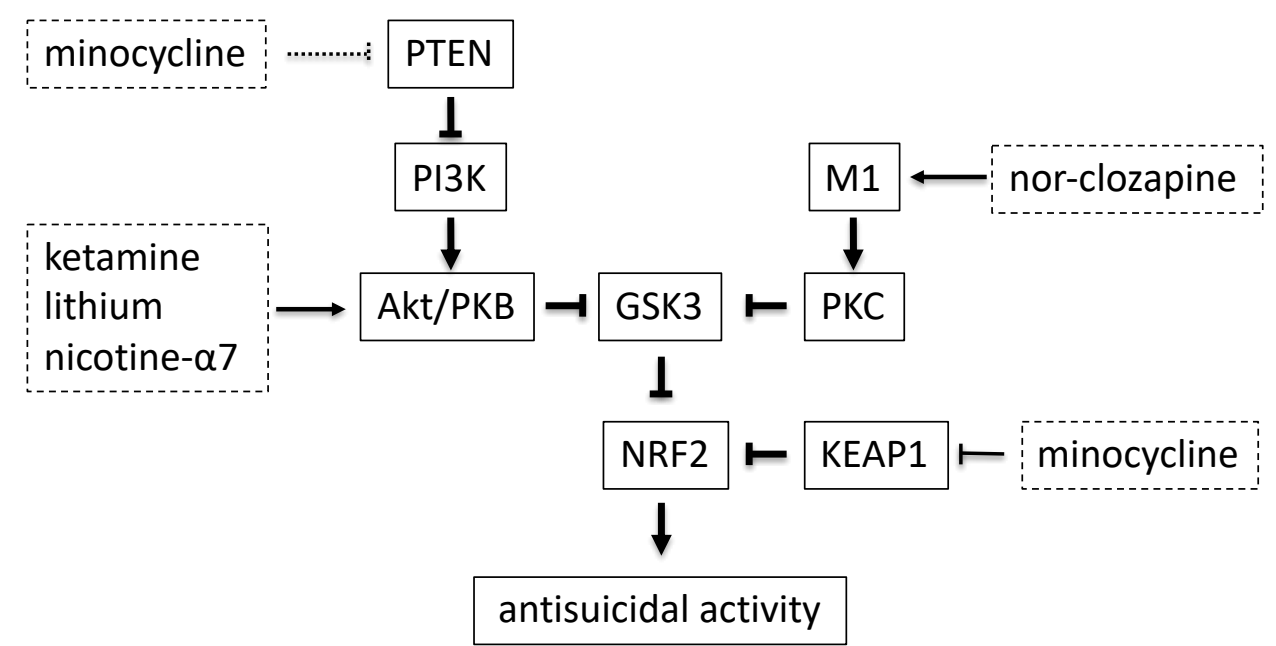

Figure 1. Schematic representation of the GSK3-NRF2 signaling pathway and its upstream modifiers. Ketamine, lithium and nicotinic- $\alpha 7$ agonists indirectly activate protein-kinase B (Akt/PKB), whereas the N-desmethyl metabolite of clozapine (norclozapine) stimulates muscarinic M1 receptors and thereby activates protein-kinase $\mathrm{C}$ (PKC). These kinases phosphorylate GSK3, which is inhibitory to GSK3's kinase activity. Active GSK3 promotes the metabolic breakdown of NRF2. An alternative way to activate NRF2 is via inhibition of the natural suppressor KEAP1. Active NRF2 is crucial for anti-oxidative and anti-inflammatory activity, which presumably results in a reduction in suicidal ideation and attempts. Minocycline could influence suicide by inhibition of KEAP1 and possibly also via the PI3K-phosphatase PTEN.

The muscarinic M1 receptor activates PKC $\beta$ and PKC $\gamma$, which in turn phosphorylate the $\beta$-isoform of GSK3 at position Serine-9. This inhibits the enzymatic activity of GSK3 $\beta$ and thus stabilizes NRF2 [99]. The muscarine agonist carbachol in rat hippocampal and cerebellar cultures increased the expression and protein levels of the NRF2-target gene, heme-oxygenase-1 (HO1) [99]. In PC12 cells, M1 activation increased mRNA and protein levels of NRF2 in the nucleus [99]. In SH-SY5Y cells, clozapine increased the levels of Ser9P-GSK3 $\beta$ [100]. Clozapine inhibits suicidal behavior in subjects with schizophrenia [7]. This is significant, since the major metabolite of clozapine, nor-clozapine, functionally acts as selective M1-receptor agonist [101]. It is conceivable that the M1-activity of nor-clozapine stabilizes NRF2 and therefore reduces the risk of suicide.

Ketamine is a further medication with significant anti-suicidal activity $[5,23]$. There is still discussion about the molecular target of ketamine [102,103], however it is clear that ketamine increases Ser9-phosphorylation of GSK3 $\beta$ in rodents [104,105] and in humans [106]. Consistent with the involvement of the GSK3-NRF2 signaling pathway, ketamine increased the expression of HO1 [107] and inhibited LPS-induced increases in IL-6, TNF $\alpha$, NFKB-signaling and nitric oxide production in a variety of in vitro and in vivo models (reviewed in [108]).

The nicotinic- $\alpha 7$ receptor agonist PNU282987 has also been shown to activate NRF2mediated transcription of HO1 [109], an effect that was absent after genetic knock-out of NRF2 or after inhibition of the nicotinic- $\alpha 7$ receptor [109]. In neuroblastoma cells, the activation of nicotinic- $\alpha 7$ receptors prevented apoptosis by activation of a signaling cascade involving JAK2-PKB-GSK3-inhibition, activation of NRF2 and subsequent HO1 transcription [14]. The same pathway increased mitochondrial numbers, mitochondrial function and ATP production in primary cultures of rat microglia [15]. Based on these data, it is quite likely that agonists of the nicotinic- $\alpha 7$ receptor could be active as prophylactic agents for suicide.

\section{KEAP1 Modulation by Minocycline}

As mentioned above, an alternative way to activate NRF2 signaling is via modulation of the natural NRF2-inhibitor KEAP1 $[9,10]$. This is, in principle achieved by electrophiles like sulforaphane or dimethyl fumarate [11,110]. It seems that also minocycline belongs to 
this group [10]. Minocycline has been shown to protect human neuroglioma cells [111] and mouse neuron/astrocyte cultures [112] via an increased activation of NRF2, while its cytoprotective effects in a model of diabetic nephropathy were abolished in mice with a genetic deletion of the NRF2-gene [113]. Moreover, in preclinical studies minocycline protected against a wide array of inflammatory conditions like LPS, stress, hypoxia, ovalbumin or retrovirus [16,114,115]. Against this background, one may propose to test minocycline as prophylactic agent against suicide.

\section{Discussion}

In this review, we have seen that suicide is associated with numerous inflammatory conditions. Mutations in genes that promote the activation of the pro-inflammatory kinase GSK3 are associated with an increased risk of suicide. Active GSK3 inhibits the function of the transcription factor NRF2, and thereby suppresses transcription of genes coding for proteins with anti-oxidative and anti-inflammatory functions. A reduction in the activity of NRF2 is a "hallmark" of aging [116], whereas aging increases the risk for suicide [117,118]. Moreover, a large meta-analysis of serum lipid levels in suicidal individuals noted that, in comparison to healthy controls, the suicidal patients had significantly lower total cholesterol, LDL-cholesterol and HDL-cholesterol levels [68], while almost identical results were published for mice with a genetic deletion of NRF2 [119]. Medications known to reduce the risk of suicide, like lithium, ketamine, or clozapine, indirectly inhibit GSK3. Whilst such data provide direct evidence for a role of GSK3 in suicide, the evidence for an involvement of NRF2 remains circumstantial.

Since GSK3 inhibition seems to provide protection against suicide, one may therefore predict that nicotinic- $\alpha 7$ agonists could be useful therapeutics for suicide prevention. Unfortunately, selective nicotinic- $\alpha 7$ agonists have not yet reached the market. The 5HT3 receptor antagonist tropisetron, which improved negative symptoms in schizophrenia patients, at relevant concentrations also stimulates nicotinic- $\alpha 7$ receptors [120]. Whether tropisetron has anti-suicidal effects in schizophrenia patients has not been studied.

Due to an interaction with the NRF2-inhibitor KEAP1, minocycline activates NRF2 transcriptional activity. It could therefore possess anti-suicidal activity. This prediction is, however, uncertain, because the evidence for a role of NRF2 in suicide is indirect. Nevertheless, there are reasons to assume that minocycline will also indirectly inhibit GSK3. This is based on the following reasoning. The enzyme phosphatidyl inositol-3 kinase (PI3K) phosphorylates and thereby activates Akt/PKB, and thus inhibits GSK3 $[9,10]$. The activity of PI3K is suppressed by the phosphatase PTEN [121]. Similar to KEAP1, PTEN contains cysteine residues that are susceptible to electrophilic compounds. For instance, the electrophile dimethyl-fumarate inhibits PTEN, and therefore activates the PI3K-PKB pathway [10]. The same effect would be predicted for minocycline, although this remains to be tested. Based on these considerations, and given the safety profile of minocycline, it could be worthwhile to test if minocycline would reduce suicide risk. It should be possible to produce derivatives of minocycline that are devoid of bacteriostatic activity, and thus would possess a reduced propensity to disturb the bacterial flora in the intestinal tract. Apparently, a considerable number of electrophilic anti-inflammatory compounds are currently in pharmaceutical development [10-12,16]. Since the exact mechanism of ketamine is still a matter of debate, it might also be fruitful to investigate if ketamine (or one of its metabolites) interferes with NRF2 function via an effect on KEAP1.

Whereas depression is in many cases a low-grade inflammatory disease [122], this does not imply that each inflammatory condition causes depression symptoms. As mentioned above, suicide has been noted in inflammatory conditions that are unrelated to the severity of depression [31-37]. This means that depression symptoms, although important, are not sufficient to predict suicide. For this reason, levels of CRP or IL-6, which are general signals of inflammation, are likely more comprehensive biomarkers for suicide risk than depression scores. The inflammatory process not only relates to suicide ideation, but may also increase the chance of a suicide act. One causal link between inflammation and suicide act is 
presumably via IL-6-induced IDO activation, which redirects tryptophan metabolism away from serotonin and melatonin synthesis towards the kynurenine-quinolinic acid metabolic pathway $[34,123]$. As mentioned before, the actual suicide act seems to be associated with irritability, hypervigilance and aggression [21,25]. The depletion of tryptophan caused a marked increase in aggression in males with a high aggression-trait [124]. Low CSF 5-HIAA levels, which are causally related to low tryptophan levels, were also found to associate with aggression and high-lethality suicide [21,125]. Sleep deprivation, possibly due to an abnormal functioning of the circadian system [126], increases anger, short-temperedness, outward-expressed aggressive impulses and delinquency [127,128]. Inflammation affects the function of clock genes [129] and melatonin synthesis. Indeed, low melatonin levels were associated with an increase in the risk of suicide [130,131]. Moreover, Levey et al. [132] who applied a "convergent functional genomics" approach to prioritize candidate biomarkers for suicide noticed an overrepresentation of clock genes among their top candidates. In conclusion, this short summary indicates that inflammatory processes not only increase suicidal ideation, but also promote behaviors that may lead to the actual suicide attempt.

This point reinforces the importance of reducing inflammation by NRF2 stimulation. Transcription of NRF2 target genes like HO1 or NQO1 could function as biomarker and would be readily assayable in, for instance, blood cells $[10,133]$. These biomarkers could also be used to optimize the dose of potential medications.

\title{
8. Conclusions
}

Nicotinic- $\alpha 7$ agonists and selective NRF2-activating compounds are currently under pharmaceutical development for a number of indications, but not for the prevention of suicide. As argued in the current article, such compounds may reduce the number of suicides. Minocycline is a further option and could be evaluated in the clinic almost immediately. However, as a first step, the psychiatric and pharmaceutical communities should become aware of the relevance of the GSK3-NRF2 axis in the pathophysiology of suicide. It is hoped that the current article will make at least a small contribution towards this goal.

Funding: This research received no external funding.

Institutional Review Board Statement: Not applicable.

Informed Consent Statement: Not applicable.

Data Availability Statement: All data are available in the quoted papers.

Conflicts of Interest: The author declares no conflict of interest.

\begin{abstract}
Abbreviations
ADHD (attention deficit hyperactivity disorder), BCL2 (B-cell lymphoma-2) and BCL $\mathrm{XL}_{\mathrm{L}}$ (B-cell lymphoma extra-large), BDNF (brain-derived neurotrophic factor), $\beta$ - $\operatorname{TrCP}$ ( $\beta$-transducin repeat containing protein), COX2 (cyclooxygenase-2), CRP (C-reactive protein), CSF (cerebrospinal fluid), CUL3/RBX1 (cullin-3/RING box protein-1), FKBP5 (FK506 binding protein-5; also known as FKBP51), GSK3 (glycogen synthase kinase-3), HIV (human immunodeficiency virus), HO1 (heme oxygenase-1), 5-HIAA (5-hydroxyindoleacetic acid), IBA1 (ionized calcium binding adaptor molecule-1), IDO1 (Indoleamine 2,3-dioxygenase-1), IL-\# (interleukin-\#), IL1-RA (interleukin-1 receptor antagonist), iNOS (inducible nitric-oxide), KEAP1 (Kelch-like erythroid cell-derived protein with CNC homology (ECH)-associated protein-1), LPS (lipopolysaccharide), MDD (major depressive disorder), MS (multiple sclerosis), NFKB (nuclear factor-kB), NQO1 (NADPH:quinone oxidoreductase-1), NRF2 (nuclear factor erythroid-2 related factor-2), PBMC (peripheral blood mononuclear cell), PHLPP (PH-domain leucine-rich repeat protein-phosphatase), PI3K (phosphatidyl inositol-3 kinase), PKB (protein kinase B, also known as 'Akt'), PKC (protein kinase C), PTEN (phosphatase and tensin homolog), PTSD (post-traumatic stress disorder), SAT1 (spermidine/spermine N1-acetyltransferase-1), SNP (single nucleotide polymorphism), SOCS3 (suppressor of cytokine signaling-3), TNF $\alpha$ (tumor necrosis factor- $\alpha$ ), TPH2 (tryptophan hydroxylase-2).
\end{abstract}




\section{References}

1. Pandey, G.N.; Sharma, A.; Rizavi, H.S.; Ren, X. Dysregulation of protein kinase c in adult depression and suicide: Evidence from postmortem brain studies. Int. J. Neuropsychopharmacol. 2021. [CrossRef]

2. Bentley, K.H.; Franklin, J.C.; Ribeiro, J.D.; Kleiman, E.M.; Fox, K.R.; Nock, M.K. Anxiety and its disorders as risk factors for suicidal thoughts and behaviors: A meta-analytic review. Clin. Psychol. Rev. 2016, 43, 30-46. [CrossRef]

3. Ribeiro, J.D.; Franklin, J.C.; Fox, K.R.; Bentley, K.H.; Kleiman, E.M.; Chang, B.P.; Nock, M.K. Self-injurious thoughts and behaviors as risk factors for future suicide ideation, attempts, and death: A meta-analysis of longitudinal studies. Psychol. Med. 2016, 46, 225-236. [CrossRef]

4. Garcia de la Garza, A.; Blanco, C.; Olfson, M.; Wall, M.M. Identification of suicide attempt risk factors in a national us survey using machine learning. JAMA Psychiatry 2021. [CrossRef] [PubMed]

5. Price, R.B.; Nock, M.K.; Charney, D.S.; Mathew, S.J. Effects of intravenous ketamine on explicit and implicit measures of suicidality in treatment-resistant depression. Biol. Psychiatry 2009, 66, 522-526. [CrossRef] [PubMed]

6. Cipriani, A.; Pretty, H.; Hawton, K.; Geddes, J.R. Lithium in the prevention of suicidal behavior and all-cause mortality in patients with mood disorders: A systematic review of randomized trials. Am. J. Psychiatry 2005, 162, 1805-1819. [CrossRef] [PubMed]

7. Meltzer, H.Y.; Alphs, L.; Green, A.I.; Altamura, A.C.; Anand, R.; Bertoldi, A.; Bourgeois, M.; Chouinard, G.; Islam, M.Z.; Kane, J.; et al. Clozapine treatment for suicidality in schizophrenia: International suicide prevention trial (intersept). Arch. Gen. Psychiatry 2003, 60, 82-91. [CrossRef] [PubMed]

8. Ma, Q. Role of nrf2 in oxidative stress and toxicity. Annu. Rev. Pharmacol. Toxicol. 2013, 53, 401-426. [CrossRef] [PubMed]

9. Bellezza, I.; Giambanco, I.; Minelli, A.; Donato, R. Nrf2-keap1 signaling in oxidative and reductive stress. Biochim. Biophys. Acta Mol. Cell Res. 2018, 1865, 721-733. [CrossRef]

10. Cuadrado, A.; Manda, G.; Hassan, A.; Alcaraz, M.J.; Barbas, C.; Daiber, A.; Ghezzi, P.; Leon, R.; Lopez, M.G.; Oliva, B.; et al. Transcription factor $\mathrm{nrf2}$ as a therapeutic target for chronic diseases: A systems medicine approach. Pharmacol. Rev. 2018, 70, 348-383. [CrossRef]

11. Dinkova-Kostova, A.T.; Kostov, R.V.; Kazantsev, A.G. The role of nrf2 signaling in counteracting neurodegenerative diseases. FEBS J. 2018, 285, 3576-3590. [CrossRef]

12. Cuadrado, A.; Rojo, A.I.; Wells, G.; Hayes, J.D.; Cousin, S.P.; Rumsey, W.L.; Attucks, O.C.; Franklin, S.; Levonen, A.L.; Kensler, T.W.; et al. Therapeutic targeting of the nrf2 and keap1 partnership in chronic diseases. Nat. Rev. Drug Discov. 2019, 18, 295-317. [CrossRef]

13. Piantadosi, C.A.; Withers, C.M.; Bartz, R.R.; MacGarvey, N.C.; Fu, P.; Sweeney, T.E.; Welty-Wolf, K.E.; Suliman, H.B. Heme oxygenase-1 couples activation of mitochondrial biogenesis to anti-inflammatory cytokine expression. J. Biol. Chem. 2011, 286, 16374-16385. [CrossRef]

14. Egea, J.; Buendia, I.; Parada, E.; Navarro, E.; Leon, R.; Lopez, M.G. Anti-inflammatory role of microglial alpha7 nachrs and its role in neuroprotection. Biochem. Pharmacol. 2015, 97, 463-472. [CrossRef]

15. Navarro, E.; Gonzalez-Lafuente, L.; Perez-Liebana, I.; Buendia, I.; Lopez-Bernardo, E.; Sanchez-Ramos, C.; Prieto, I.; Cuadrado, A.; Satrustegui, J.; Cadenas, S.; et al. Heme-oxygenase i and pcg-1alpha regulate mitochondrial biogenesis via microglial activation of alpha7 nicotinic acetylcholine receptors using pnu282987. Antioxid. Redox Signal. 2017, 27, 93-105. [CrossRef]

16. Hashimoto, K. Essential role of keap1-nrf2 signaling in mood disorders: Overview and future perspective. Front. Pharmacol. 2018, 9, 1182. [CrossRef] [PubMed]

17. Rada, P.; Rojo, A.I.; Chowdhry, S.; McMahon, M.; Hayes, J.D.; Cuadrado, A. Scf/\{beta\}-trcp promotes glycogen synthase kinase 3-dependent degradation of the nrf2 transcription factor in a keap1-independent manner. Mol. Cell. Biol. 2011, 31, 1121-1133. [CrossRef] [PubMed]

18. Rada, P.; Rojo, A.I.; Evrard-Todeschi, N.; Innamorato, N.G.; Cotte, A.; Jaworski, T.; Tobon-Velasco, J.C.; Devijver, H.; GarciaMayoral, M.F.; Van Leuven, F.; et al. Structural and functional characterization of nrf2 degradation by the glycogen synthase kinase 3/beta-trcp axis. Mol. Cell. Biol. 2012, 32, 3486-3499. [CrossRef] [PubMed]

19. Kobayashi, E.H.; Suzuki, T.; Funayama, R.; Nagashima, T.; Hayashi, M.; Sekine, H.; Tanaka, N.; Moriguchi, T.; Motohashi, H.; Nakayama, K.; et al. Nrf2 suppresses macrophage inflammatory response by blocking proinflammatory cytokine transcription. Nat. Commun. 2016, 7, 11624. [CrossRef] [PubMed]

20. Kim, S.W.; Lee, H.K.; Shin, J.H.; Lee, J.K. Up-down regulation of ho-1 and inos gene expressions by ethyl pyruvate via recruiting p300 to nrf2 and depriving it from p65. Free Radic. Biol. Med. 2013, 65, 468-476. [CrossRef]

21. Placidi, G.P.; Oquendo, M.A.; Malone, K.M.; Huang, Y.Y.; Ellis, S.P.; Mann, J.J. Aggressivity, suicide attempts, and depression: Relationship to cerebrospinal fluid monoamine metabolite levels. Biol. Psychiatry 2001, 50, 783-791. [CrossRef]

22. Brezo, J.; Paris, J.; Vitaro, F.; Hebert, M.; Tremblay, R.E.; Turecki, G. Predicting suicide attempts in young adults with histories of childhood abuse. Br. J. Psychiatry 2008, 193, 134-139. [CrossRef]

23. Ballard, E.D.; Ionescu, D.F.; Vande Voort, J.L.; Niciu, M.J.; Richards, E.M.; Luckenbaugh, D.A.; Brutsche, N.E.; Ameli, R.; Furey, M.L.; Zarate, C.A., Jr. Improvement in suicidal ideation after ketamine infusion: Relationship to reductions in depression and anxiety. J. Psychiatr. Res. 2014, 58, 161-166. [CrossRef]

24. Wiebenga, J.X.; Eikelenboom, M.; Heering, H.D.; van Oppen, P.; Penninx, B.W. Suicide ideation versus suicide attempt: Examining overlapping and differential determinants in a large cohort of patients with depression and/or anxiety. Aust. N. Z. J. Psychiatry 2021, 55, 167-179. [CrossRef] 
25. Nock, M.K.; Hwang, I.; Sampson, N.A.; Kessler, R.C. Mental disorders, comorbidity and suicidal behavior: Results from the national comorbidity survey replication. Mol. Psychiatry 2010, 15, 868-876. [CrossRef]

26. Kim, J.; Lee, K.S.; Kim, D.J.; Hong, S.C.; Choi, K.H.; Oh, Y.; Wang, S.M.; Lee, H.K.; Kweon, Y.S.; Lee, C.T.; et al. Characteristic risk factors associated with planned versus impulsive suicide attempters. Clin. Psychopharmacol. Neurosci. 2015, 13, 308-315. [CrossRef] [PubMed]

27. Gradus, J.L.; Qin, P.; Lincoln, A.K.; Miller, M.; Lawler, E.; Sorensen, H.T.; Lash, T.L. Posttraumatic stress disorder and completed suicide. Am. J. Epidemiol. 2010, 171, 721-727. [CrossRef] [PubMed]

28. Fox, V.; Dalman, C.; Dal, H.; Hollander, A.C.; Kirkbride, J.B.; Pitman, A. Suicide risk in people with post-traumatic stress disorder: A cohort study of 3.1 million people in sweden. J. Affect. Disord. 2021, 279, 609-616. [CrossRef] [PubMed]

29. Oswald, P.; Souery, D.; Kasper, S.; Lecrubier, Y.; Montgomery, S.; Wyckaert, S.; Zohar, J.; Mendlewicz, J. Current issues in bipolar disorder: A critical review. Eur. Neuropsychopharmacol. 2007, 17, 687-695. [CrossRef]

30. Sharma, T.; Guski, L.S.; Freund, N.; Gotzsche, P.C. Suicidality and aggression during antidepressant treatment: Systematic review and meta-analyses based on clinical study reports. BMJ 2016, 352, i65. [CrossRef] [PubMed]

31. Steiner, J.; Bielau, H.; Brisch, R.; Danos, P.; Ullrich, O.; Mawrin, C.; Bernstein, H.G.; Bogerts, B. Immunological aspects in the neurobiology of suicide: Elevated microglial density in schizophrenia and depression is associated with suicide. J. Psychiatr. Res. 2008, 42, 151-157. [CrossRef]

32. Falcone, T.; Fazio, V.; Lee, C.; Simon, B.; Franco, K.; Marchi, N.; Janigro, D. Serum s100b: A potential biomarker for suicidality in adolescents? PLoS ONE 2010, 5, e11089. [CrossRef]

33. Webb, R.T.; Kontopantelis, E.; Doran, T.; Qin, P.; Creed, F.; Kapur, N. Suicide risk in primary care patients with major physical diseases: A case-control study. Arch. Gen. Psychiatry 2012, 69, 256-264. [CrossRef] [PubMed]

34. Erhardt, S.; Lim, C.K.; Linderholm, K.R.; Janelidze, S.; Lindqvist, D.; Samuelsson, M.; Lundberg, K.; Postolache, T.T.; TraskmanBendz, L.; Guillemin, G.J.; et al. Connecting inflammation with glutamate agonism in suicidality. Neuropsychopharmacology 2013, 38, 743-752. [CrossRef] [PubMed]

35. O'Donovan, A.; Rush, G.; Hoatam, G.; Hughes, B.M.; McCrohan, A.; Kelleher, C.; O'Farrelly, C.; Malone, K.M. Suicidal ideation is associated with elevated inflammation in patients with major depressive disorder. Depress Anxiety 2013, 30, 307-314. [CrossRef] [PubMed]

36. Black, C.; Miller, B.J. Meta-analysis of cytokines and chemokines in suicidality: Distinguishing suicidal versus nonsuicidal patients. Biol. Psychiatry 2015, 78, 28-37. [CrossRef] [PubMed]

37. Bergmans, R.S.; Kelly, K.M.; Mezuk, B. Inflammation as a unique marker of suicide ideation distinct from depression syndrome among U.S. adults. J. Affect. Disord. 2019, 245, 1052-1060. [CrossRef] [PubMed]

38. Brundin, L.; Erhardt, S.; Bryleva, E.Y.; Achtyes, E.D.; Postolache, T.T. The role of inflammation in suicidal behaviour. Acta Psychiatr. Scand. 2015, 132, 192-203. [CrossRef] [PubMed]

39. Beurel, E.; Jope, R.S. Inflammation and lithium: Clues to mechanisms contributing to suicide-linked traits. Transl. Psychiatry 2014, 4, e488. [CrossRef]

40. Lund-Sorensen, H.; Benros, M.E.; Madsen, T.; Sorensen, H.J.; Eaton, W.W.; Postolache, T.T.; Nordentoft, M.; Erlangsen, A. A nationwide cohort study of the association between hospitalization with infection and risk of death by suicide. JAMA Psychiatry 2016, 73, 912-919. [CrossRef]

41. Arling, T.A.; Yolken, R.H.; Lapidus, M.; Langenberg, P.; Dickerson, F.B.; Zimmerman, S.A.; Balis, T.; Cabassa, J.A.; Scrandis, D.A.; Tonelli, L.H.; et al. Toxoplasma gondii antibody titers and history of suicide attempts in patients with recurrent mood disorders. J. Nerv. Ment. Dis. 2009, 197, 905-908. [CrossRef] [PubMed]

42. Okusaga, O.; Langenberg, P.; Sleemi, A.; Vaswani, D.; Giegling, I.; Hartmann, A.M.; Konte, B.; Friedl, M.; Groer, M.W.; Yolken, R.H.; et al. Toxoplasma gondii antibody titers and history of suicide attempts in patients with schizophrenia. Schizophr. Res. 2011, 133, 150-155. [CrossRef] [PubMed]

43. Hsu, P.C.; Groer, M.; Beckie, T. New findings: Depression, suicide, and toxoplasma gondii infection. J. Am. Assoc. Nurse Pract. 2014, 26, 629-637. [CrossRef]

44. Calati, R.; Courtet, P.; Norton, J.; Ritchie, K.; Artero, S. Association between lifetime headache and history of suicide attempts in the elderly. Eur. Psychiatry 2017, 41, 132-139. [CrossRef]

45. Messias, E.; Clarke, D.E.; Goodwin, R.D. Seasonal allergies and suicidality: Results from the national comorbidity survey replication. Acta Psychiatr. Scand. 2010, 122, 139-142. [CrossRef]

46. Jeon-Slaughter, H.; Claassen, C.A.; Khan, D.A.; Mihalakos, P.; Lee, K.B.; Brown, E.S. Temporal association between nonfatal self-directed violence and tree and grass pollen counts. J. Clin. Psychiatry 2016, 77, 1160-1167. [CrossRef]

47. Chung, J.H.; Kim, S.H.; Lee, Y.W. Suicidal ideation and suicide attempts among asthma. Ann. Gen. Psychiatry 2016, 15, 35. [CrossRef]

48. Tonelli, L.H.; Stiller, J.; Rujescu, D.; Giegling, I.; Schneider, B.; Maurer, K.; Schnabel, A.; Moller, H.J.; Chen, H.H.; Postolache, T.T. Elevated cytokine expression in the orbitofrontal cortex of victims of suicide. Acta Psychiatr. Scand. 2008, 117, 198-206. [CrossRef]

49. Fegg, M.; Kraus, S.; Graw, M.; Bausewein, C. Physical compared to mental diseases as reasons for committing suicide: A retrospective study. BMC Palliat. Care 2016, 15, 14. [CrossRef]

50. Torres, M.E.; Lowe, B.; Schmitz, S.; Pienta, J.N.; Van Der Feltz-Cornelis, C.; Fiedorowicz, J.G. Suicide and suicidality in somatic symptom and related disorders: A systematic review. J. Psychosom. Res. 2021, 140, 110290. [CrossRef] [PubMed] 
51. Wagner, B.; Klinitzke, G.; Brahler, E.; Kersting, A. Extreme obesity is associated with suicidal behavior and suicide attempts in adults: Results of a population-based representative sample. Depress. Anxiety 2013, 30, 975-981. [CrossRef] [PubMed]

52. Eriksson, M.; Glader, E.L.; Norrving, B.; Asplund, K. Poststroke suicide attempts and completed suicides: A socioeconomic and nationwide perspective. Neurology 2015, 84, 1732-1738. [CrossRef] [PubMed]

53. Fralick, M.; Thiruchelvam, D.; Tien, H.C.; Redelmeier, D.A. Risk of suicide after a concussion. CMAJ 2016, 188, 497-504. [CrossRef] [PubMed]

54. Nerurkar, L.; Siebert, S.; McInnes, I.B.; Cavanagh, J. Rheumatoid arthritis and depression: An inflammatory perspective. Lancet Psychiatry 2019, 6, 164-173. [CrossRef]

55. Finkelsztejn, A.; Fragoso, Y.D.; Ferreira, M.L.; Lana-Peixoto, M.A.; Alves-Leon, S.V.; Gomes, S.; Damasceno, B.P.; Mendes, M.F.; Salgado, P.R.; Correa, E.C.; et al. The brazilian database on pregnancy in multiple sclerosis. Clin. Neurol. Neurosurg. 2011, 113, 277-280. [CrossRef]

56. Lindqvist, D.; Janelidze, S.; Hagell, P.; Erhardt, S.; Samuelsson, M.; Minthon, L.; Hansson, O.; Bjorkqvist, M.; Traskman-Bendz, L.; Brundin, L. Interleukin-6 is elevated in the cerebrospinal fluid of suicide attempters and related to symptom severity. Biol. Psychiatry 2009, 66, 287-292. [CrossRef] [PubMed]

57. Isung, J.; Aeinehband, S.; Mobarrez, F.; Nordstrom, P.; Runeson, B.; Asberg, M.; Piehl, F.; Jokinen, J. High interleukin-6 and impulsivity: Determining the role of endophenotypes in attempted suicide. Transl. Psychiatry 2014, 4, e470. [CrossRef] [PubMed]

58. Gananca, L.; Oquendo, M.A.; Tyrka, A.R.; Cisneros-Trujillo, S.; Mann, J.J.; Sublette, M.E. The role of cytokines in the pathophysiology of suicidal behavior. Psychoneuroendocrinology 2016, 63, 296-310. [CrossRef] [PubMed]

59. Sublette, M.E.; Galfalvy, H.C.; Fuchs, D.; Lapidus, M.; Grunebaum, M.F.; Oquendo, M.A.; Mann, J.J.; Postolache, T.T. Plasma kynurenine levels are elevated in suicide attempters with major depressive disorder. Brain Behav. Immun. 2011, 25, 1272-1278. [CrossRef]

60. Parrott, J.M.; O'Connor, J.C. Kynurenine 3-monooxygenase: An influential mediator of neuropathology. Front. Psychiatry 2015, 6, 116. [CrossRef]

61. Carlborg, A.; Jokinen, J.; Jonsson, E.G.; Erhardt, S.; Nordstrom, P. Csf kynurenic acid and suicide risk in schizophrenia spectrum psychosis. Psychiatry Res. 2013, 205, 165-167. [CrossRef]

62. Courtet, P.; Jaussent, I.; Genty, C.; Dupuy, A.M.; Guillaume, S.; Ducasse, D.; Olie, E. Increased crp levels may be a trait marker of suicidal attempt. Eur. Neuropsychopharmacol. 2015, 25, 1824-1831. [CrossRef]

63. Gibbs, H.M.; Davis, L.; Han, X.; Clothier, J.; Eads, L.A.; Caceda, R. Association between c-reactive protein and suicidal behavior in an adult inpatient population. J. Psychiatr. Res. 2016, 79, 28-33. [CrossRef]

64. Fiori, L.M.; Bureau, A.; Labbe, A.; Croteau, J.; Noel, S.; Merette, C.; Turecki, G. Global gene expression profiling of the polyamine system in suicide completers. Int. J. Neuropsychopharmacol. 2011, 14, 595-605. [CrossRef] [PubMed]

65. Le-Niculescu, H.; Levey, D.F.; Ayalew, M.; Palmer, L.; Gavrin, L.M.; Jain, N.; Winiger, E.; Bhosrekar, S.; Shankar, G.; Radel, M.; et al. Discovery and validation of blood biomarkers for suicidality. Mol. Psychiatry 2013, 18, 1249-1264. [CrossRef] [PubMed]

66. Schnieder, T.P.; Trencevska, I.; Rosoklija, G.; Stankov, A.; Mann, J.J.; Smiley, J.; Dwork, A.J. Microglia of prefrontal white matter in suicide. J. Neuropathol. Exp. Neurol. 2014, 73, 880-890. [CrossRef] [PubMed]

67. Russell, A.E.; Mars, B.; Wen, C.P.; Chang, S.S.; Gunnell, D. Evidence for an association between inflammatory markers and suicide: A cohort study based on 359,849 to 462,747 taiwanese adults. J. Affect. Disord. 2021, 281, 967-971. [CrossRef]

68. Wu, S.; Ding, Y.; Wu, F.; Xie, G.; Hou, J.; Mao, P. Serum lipid levels and suicidality: A meta-analysis of 65 epidemiological studies. J. Psychiatry Neurosci. 2016, 41, 56-69. [CrossRef]

69. Suneson, K.; Asp, M.; Traskman-Bendz, L.; Westrin, A.; Ambrus, L.; Lindqvist, D. Low total cholesterol and low-density lipoprotein associated with aggression and hostility in recent suicide attempters. Psychiatry Res. 2019, 273, 430-434. [CrossRef]

70. Kulak-Bejda, A.; Bejda, G.; Lech, M.; Waszkiewicz, N. Are lipids possible markers of suicide behaviors? J. Clin. Med. 2021, 10, 333. [CrossRef]

71. Tatro, E.T.; Everall, I.P.; Masliah, E.; Hult, B.J.; Lucero, G.; Chana, G.; Soontornniyomkij, V.; Achim, C.L.; Center, H.I.V.N.R. Differential expression of immunophilins fkbp51 and fkbp52 in the frontal cortex of hiv-infected patients with major depressive disorder. J. Neuroimmune Pharmacol. 2009, 4, 218-226. [CrossRef]

72. Lekman, M.; Laje, G.; Charney, D.; Rush, A.J.; Wilson, A.F.; Sorant, A.J.; Lipsky, R.; Wisniewski, S.R.; Manji, H.; McMahon, F.J.; et al. The fkbp5-gene in depression and treatment response-an association study in the sequenced treatment alternatives to relieve depression (star*d) cohort. Biol. Psychiatry 2008, 63, 1103-1110. [CrossRef]

73. Willour, V.L.; Chen, H.; Toolan, J.; Belmonte, P.; Cutler, D.J.; Goes, F.S.; Zandi, P.P.; Lee, R.S.; MacKinnon, D.F.; Mondimore, F.M.; et al. Family-based association of fkbp5 in bipolar disorder. Mol. Psychiatry 2009, 14, 261-268. [CrossRef] [PubMed]

74. Brent, D.; Melhem, N.; Ferrell, R.; Emslie, G.; Wagner, K.D.; Ryan, N.; Vitiello, B.; Birmaher, B.; Mayes, T.; Zelazny, J.; et al. Association of fkbp5 polymorphisms with suicidal events in the treatment of resistant depression in adolescents (tordia) study. Am. J. Psychiatry 2010, 167, 190-197. [CrossRef] [PubMed]

75. Roy, A.; Gorodetsky, E.; Yuan, Q.; Goldman, D.; Enoch, M.A. Interaction of fkbp5, a stress-related gene, with childhood trauma increases the risk for attempting suicide. Neuropsychopharmacology 2010, 35, 1674-1683. [CrossRef]

76. Supriyanto, I.; Sasada, T.; Fukutake, M.; Asano, M.; Ueno, Y.; Nagasaki, Y.; Shirakawa, O.; Hishimoto, A. Association of fkbp5 gene haplotypes with completed suicide in the japanese population. Prog. Neuropsychopharmacol. Biol. Psychiatry 2011, 35, 252-256. [CrossRef] [PubMed] 
77. Hernandez-Diaz, Y.; Gonzalez-Castro, T.B.; Tovilla-Zarate, C.A.; Juarez-Rojop, I.E.; Lopez-Narvaez, M.L.; Perez-Hernandez, N.; Rodriguez-Perez, J.M.; Genis-Mendoza, A.D. Association between polymorphisms of fkbp5 gene and suicide attempt in a mexican population: A case-control study. Brain Res. Bull. 2021, 166, 37-43. [CrossRef] [PubMed]

78. Jackson, T.C.; Verrier, J.D.; Semple-Rowland, S.; Kumar, A.; Foster, T.C. Phlpp1 splice variants differentially regulate akt and pkcalpha signaling in hippocampal neurons: Characterization of phlpp proteins in the adult hippocampus. J. Neurochem. 2010, 115, 941-955. [CrossRef]

79. Mistafa, O.; Ghalali, A.; Kadekar, S.; Hogberg, J.; Stenius, U. Purinergic receptor-mediated rapid depletion of nuclear phosphorylated akt depends on pleckstrin homology domain leucine-rich repeat phosphatase, calcineurin, protein phosphatase $2 \mathrm{a}$, and pten phosphatases. J. Biol. Chem. 2010, 285, 27900-27910. [CrossRef]

80. O'Neill, A.K.; Niederst, M.J.; Newton, A.C. Suppression of survival signalling pathways by the phosphatase phlpp. FEBS J. 2013, 280, 572-583. [CrossRef]

81. Hsiung, S.C.; Adlersberg, M.; Arango, V.; Mann, J.J.; Tamir, H.; Liu, K.P. Attenuated 5-ht1a receptor signaling in brains of suicide victims: Involvement of adenylyl cyclase, phosphatidylinositol 3-kinase, akt and mitogen-activated protein kinase. J. Neurochem. 2003, 87, 182-194. [CrossRef] [PubMed]

82. Karege, F.; Perroud, N.; Burkhardt, S.; Schwald, M.; Ballmann, E.; La Harpe, R.; Malafosse, A. Alteration in kinase activity but not in protein levels of protein kinase $b$ and glycogen synthase kinase-3beta in ventral prefrontal cortex of depressed suicide victims. Biol. Psychiatry 2007, 61, 240-245. [CrossRef]

83. Pandey, G.N.; Dwivedi, Y.; Rizavi, H.S.; Ren, X.; Conley, R.R. Decreased catalytic activity and expression of protein kinase c isozymes in teenage suicide victims: A postmortem brain study. Arch. Gen. Psychiatry 2004, 61, 685-693. [CrossRef]

84. Ren, X.; Rizavi, H.S.; Khan, M.A.; Dwivedi, Y.; Pandey, G.N. Altered wnt signalling in the teenage suicide brain: Focus on glycogen synthase kinase-3beta and beta-catenin. Int. J. Neuropsychopharmacol. 2013, 16, 945-955. [CrossRef] [PubMed]

85. Zill, P.; Buttner, A.; Eisenmenger, W.; Moller, H.J.; Bondy, B.; Ackenheil, M. Single nucleotide polymorphism and haplotype analysis of a novel tryptophan hydroxylase isoform (tph2) gene in suicide victims. Biol. Psychiatry 2004, 56, 581-586. [CrossRef]

86. Bach-Mizrachi, H.; Underwood, M.D.; Kassir, S.A.; Bakalian, M.J.; Sibille, E.; Tamir, H.; Mann, J.J.; Arango, V. Neuronal tryptophan hydroxylase mrna expression in the human dorsal and median raphe nuclei: Major depression and suicide. Neuropsychopharmacology 2006, 31, 814-824. [CrossRef]

87. Lopez de Lara, C.; Brezo, J.; Rouleau, G.; Lesage, A.; Dumont, M.; Alda, M.; Benkelfat, C.; Turecki, G. Effect of tryptophan hydroxylase-2 gene variants on suicide risk in major depression. Biol. Psychiatry 2007, 62, 72-80. [CrossRef]

88. Lopez, V.A.; Detera-Wadleigh, S.; Cardona, I.; Kassem, L.; McMahon, F.J.; National Institute of Mental Health Genetics Initiative Bipolar Disorder Consortium. Nested association between genetic variation in tryptophan hydroxylase ii, bipolar affective disorder, and suicide attempts. Biol. Psychiatry 2007, 61, 181-186. [CrossRef]

89. Yoon, H.K.; Kim, Y.K. Tph2 -703g/t snp may have important effect on susceptibility to suicidal behavior in major depression. Prog. Neuropsychopharmacol. Biol. Psychiatry 2009, 33, 403-409. [CrossRef]

90. Zhang, Y.; Zhang, C.; Yuan, G.; Yao, J.; Cheng, Z.; Liu, C.; Liu, Q.; Wan, G.; Shi, G.; Cheng, Y.; et al. Effect of tryptophan hydroxylase-2 rs7305115 snp on suicide attempts risk in major depression. Behav. Brain Funct. 2010, 6, 49. [CrossRef] [PubMed]

91. Zupanc, T.; Pregelj, P.; Tomori, M.; Komel, R.; Paska, A.V. Tph2 polymorphisms and alcohol-related suicide. Neurosci. Lett. 2011, 490, 78-81. [CrossRef]

92. Beaulieu, J.M.; Zhang, X.; Rodriguiz, R.M.; Sotnikova, T.D.; Cools, M.J.; Wetsel, W.C.; Gainetdinov, R.R.; Caron, M.G. Role of gsk3 beta in behavioral abnormalities induced by serotonin deficiency. Proc. Natl. Acad. Sci. USA 2008, 105, 1333-1338. [CrossRef] [PubMed]

93. Chalecka-Franaszek, E.; Chuang, D.M. Lithium activates the serine/threonine kinase akt-1 and suppresses glutamate-induced inhibition of akt-1 activity in neurons. Proc. Natl. Acad. Sci. USA 1999, 96, 8745-8750. [CrossRef]

94. Zhang, F.; Phiel, C.J.; Spece, L.; Gurvich, N.; Klein, P.S. Inhibitory phosphorylation of glycogen synthase kinase-3 (gsk-3) in response to lithium. Evidence for autoregulation of gsk-3. J. Biol. Chem. 2003, 278, 33067-33077. [CrossRef]

95. Freland, L.; Beaulieu, J.M. Inhibition of gsk3 by lithium, from single molecules to signaling networks. Front. Mol. Neurosci. 2012, 5, 14. [CrossRef]

96. Salazar, M.; Rojo, A.I.; Velasco, D.; de Sagarra, R.M.; Cuadrado, A. Glycogen synthase kinase-3beta inhibits the xenobiotic and antioxidant cell response by direct phosphorylation and nuclear exclusion of the transcription factor nrf2. J. Biol. Chem. 2006, 281, 14841-14851. [CrossRef]

97. Rojo, A.I.; Rada, P.; Egea, J.; Rosa, A.O.; Lopez, M.G.; Cuadrado, A. Functional interference between glycogen synthase kinase-3 beta and the transcription factor nrf2 in protection against kainate-induced hippocampal cell death. Mol. Cell. Neurosci. 2008, 39, 125-132. [CrossRef]

98. Rizak, J.; Tan, H.; Zhu, H.; Wang, J.F. Chronic treatment with the mood-stabilizing drug lithium up-regulates nuclear factor e2-related factor 2 in rat pheochromocytoma pc12 cells in vitro. Neuroscience 2014, 256, 223-229. [CrossRef] [PubMed]

99. Espada, S.; Rojo, A.I.; Salinas, M.; Cuadrado, A. The muscarinic $\mathrm{m} 1$ receptor activates nrf2 through a signaling cascade that involves protein kinase $\mathrm{c}$ and inhibition of gsk-3beta: Connecting neurotransmission with neuroprotection. J. Neurochem. 2009, 110, 1107-1119. [CrossRef] [PubMed]

100. Kang, U.G.; Seo, M.S.; Roh, M.S.; Kim, Y.; Yoon, S.C.; Kim, Y.S. The effects of clozapine on the gsk-3-mediated signaling pathway. FEBS Lett. 2004, 560, 115-119. [CrossRef] 
101. Sur, C.; Mallorga, P.J.; Wittmann, M.; Jacobson, M.A.; Pascarella, D.; Williams, J.B.; Brandish, P.E.; Pettibone, D.J.; Scolnick, E.M.; Conn, P.J. N-desmethylclozapine, an allosteric agonist at muscarinic 1 receptor, potentiates n-methyl-d-aspartate receptor activity. Proc. Natl. Acad. Sci. USA 2003, 100, 13674-13679. [CrossRef]

102. Zanos, P.; Gould, T.D. Mechanisms of ketamine action as an antidepressant. Mol. Psychiatry 2018, 23, 801-811. [CrossRef]

103. Abdallah, C.G.; Sanacora, G.; Duman, R.S.; Krystal, J.H. The neurobiology of depression, ketamine and rapid-acting antidepressants: Is it glutamate inhibition or activation? Pharmacol. Ther. 2018, 190, 148-158. [CrossRef]

104. Beurel, E.; Song, L.; Jope, R.S. Inhibition of glycogen synthase kinase-3 is necessary for the rapid antidepressant effect of ketamine in mice. Mol. Psychiatry 2011, 16, 1068-1070. [CrossRef]

105. Zhou, W.; Dong, L.; Wang, N.; Shi, J.Y.; Yang, J.J.; Zuo, Z.Y.; Zhou, Z.Q. Akt mediates gsk-3beta phosphorylation in the rat prefrontal cortex during the process of ketamine exerting rapid antidepressant actions. Neuroimmunomodulation 2014, 21, 183-188. [CrossRef]

106. Yang, C.; Zhou, Z.Q.; Gao, Z.Q.; Shi, J.Y.; Yang, J.J. Acute increases in plasma mammalian target of rapamycin, glycogen synthase kinase-3beta, and eukaryotic elongation factor 2 phosphorylation after ketamine treatment in three depressed patients. Biol.Psychiatry 2013, 73, e35-e36. [CrossRef]

107. Hoetzel, A.; Schmidt, R. Regulatory role of anesthetics on heme oxygenase-1. Curr. Drug Targets 2010, 11, 1495-1503. [CrossRef] [PubMed]

108. Zunszain, P.A.; Horowitz, M.A.; Cattaneo, A.; Lupi, M.M.; Pariante, C.M. Ketamine: Synaptogenesis, immunomodulation and glycogen synthase kinase-3 as underlying mechanisms of its antidepressant properties. Mol. Psychiatry 2013, 18, 1236-1241. [CrossRef] [PubMed]

109. Parada, E.; Egea, J.; Buendia, I.; Negredo, P.; Cunha, A.C.; Cardoso, S.; Soares, M.P.; Lopez, M.G. The microglial alpha7acetylcholine nicotinic receptor is a key element in promoting neuroprotection by inducing heme oxygenase-1 via nuclear factor erythroid-2-related factor 2. Antioxid. Redox Signal. 2013, 19, 1135-1148. [CrossRef] [PubMed]

110. Rosito, M.; Testi, C.; Parisi, G.; Cortese, B.; Baiocco, P.; Di Angelantonio, S. Exploring the use of dimethyl fumarate as microglia modulator for neurodegenerative diseases treatment. Antioxidants 2020, 9, 700. [CrossRef]

111. Tian, Y.; Wu, X.; Guo, S.; Ma, L.; Huang, W.; Zhao, X. Minocycline attenuates sevoflurane-induced cell injury via activation of nrf2. Int. J. Mol. Med. 2017, 39, 869-878. [CrossRef] [PubMed]

112. Kuang, X.; Scofield, V.L.; Yan, M.; Stoica, G.; Liu, N.; Wong, P.K. Attenuation of oxidative stress, inflammation and apoptosis by minocycline prevents retrovirus-induced neurodegeneration in mice. Brain Res. 2009, 1286, 174-184. [CrossRef]

113. Shahzad, K.; Bock, F.; Al-Dabet, M.M.; Gadi, I.; Nazir, S.; Wang, H.; Kohli, S.; Ranjan, S.; Mertens, P.R.; Nawroth, P.P.; et al. Stabilization of endogenous nrf2 by minocycline protects against nlrp3-inflammasome induced diabetic nephropathy. Sci. Rep. 2016, 6, 34228. [CrossRef] [PubMed]

114. Garrido-Mesa, N.; Zarzuelo, A.; Galvez, J. Minocycline: Far beyond an antibiotic. Br. J. Pharmacol. 2013, 169, 337-352. [CrossRef]

115. Reis, D.J.; Casteen, E.J.; Ilardi, S.S. The antidepressant impact of minocycline in rodents: A systematic review and meta-analysis. Sci. Rep. 2019, 9, 261. [CrossRef] [PubMed]

116. Schmidlin, C.J.; Dodson, M.B.; Madhavan, L.; Zhang, D.D. Redox regulation by nrf2 in aging and disease. Free Radic. Biol. Med. 2019, 134, 702-707. [CrossRef] [PubMed]

117. Suresh Kumar, P.N.; Anish, P.K.; George, B. Risk factors for suicide in elderly in comparison to younger age groups. Indian J. Psychiatry 2015, 57, 249-254. [CrossRef]

118. Shah, A. The relationship between suicide rates and age: An analysis of multinational data from the world health organization. Int. Psychogeriatr. 2007, 19, 1141-1152. [CrossRef]

119. Xu, J.; Donepudi, A.C.; More, V.R.; Kulkarni, S.R.; Li, L.; Guo, L.; Yan, B.; Chatterjee, T.; Weintraub, N.; Slitt, A.L. Deficiency in nrf2 transcription factor decreases adipose tissue mass and hepatic lipid accumulation in leptin-deficient mice. Obesity 2015, 23, 335-344. [CrossRef]

120. Rowe, A.R.; Mercer, L.; Casetti, V.; Sendt, K.V.; Giaroli, G.; Shergill, S.S.; Tracy, D.K. Dementia praecox redux: A systematic review of the nicotinic receptor as a target for cognitive symptoms of schizophrenia. J. Psychopharmacol. 2015, 29, 197-211. [CrossRef]

121. Rojo, A.I.; Rada, P.; Mendiola, M.; Ortega-Molina, A.; Wojdyla, K.; Rogowska-Wrzesinska, A.; Hardisson, D.; Serrano, M.; Cuadrado, A. The pten/nrf2 axis promotes human carcinogenesis. Antioxid. Redox Signal. 2014, 21, 2498-2514. [CrossRef]

122. Berk, M.; Williams, L.J.; Jacka, F.N.; O’Neil, A.; Pasco, J.A.; Moylan, S.; Allen, N.B.; Stuart, A.L.; Hayley, A.C.; Byrne, M.L.; et al. So depression is an inflammatory disease, but where does the inflammation come from? BMC Med. 2013, 11, 200. [CrossRef] [PubMed]

123. Bansal, Y.; Singh, R.; Parhar, I.; Kuhad, A.; Soga, T. Quinolinic acid and nuclear factor erythroid 2-related factor 2 in depression: Role in neuroprogression. Front. Pharmacol. 2019, 10, 452. [CrossRef]

124. Bjork, J.M.; Dougherty, D.M.; Moeller, F.G.; Swann, A.C. Differential behavioral effects of plasma tryptophan depletion and loading in aggressive and nonaggressive men. Neuropsychopharmacology 2000, 22, 357-369. [CrossRef]

125. Mann, J.J.; Currier, D.; Stanley, B.; Oquendo, M.A.; Amsel, L.V.; Ellis, S.P. Can biological tests assist prediction of suicide in mood disorders? Int. J. Neuropsychopharmacol. 2006, 9, 465-474. [CrossRef]

126. Hood, S.; Amir, S. Biological clocks and rhythms of anger and aggression. Front. Behav. Neurosci. 2018, 12, 4. [CrossRef] [PubMed]

127. Kamphuis, J.; Meerlo, P.; Koolhaas, J.M.; Lancel, M. Poor sleep as a potential causal factor in aggression and violence. Sleep Med. 2012, 13, 327-334. [CrossRef] [PubMed] 
128. Meldrum, R.C.; Barnes, J.C.; Hay, C. Sleep deprivation, low self-control, and delinquency: A test of the strength model of self-control. J. Youth Adolesc. 2015, 44, 465-477. [CrossRef] [PubMed]

129. Dantzer, R.; O'Connor, J.C.; Freund, G.G.; Johnson, R.W.; Kelley, K.W. From inflammation to sickness and depression: When the immune system subjugates the brain. Nat. Rev. Neurosci. 2008, 9, 46-56. [CrossRef]

130. Stanley, M.; Brown, G.M. Melatonin levels are reduced in the pineal glands of suicide victims. Psychopharmacol. Bull. 1988, 24, 484-488.

131. Sandyk, R.; Awerbuch, G.I. Nocturnal melatonin secretion in suicidal patients with multiple sclerosis. Int. J. Neurosci. 1993, 71, 173-182. [CrossRef] [PubMed]

132. Levey, D.F.; Niculescu, E.M.; Le-Niculescu, H.; Dainton, H.L.; Phalen, P.L.; Ladd, T.B.; Weber, H.; Belanger, E.; Graham, D.L.; Khan, F.N.; et al. Towards understanding and predicting suicidality in women: Biomarkers and clinical risk assessment. Mol. Psychiatry 2016, 21, 768-785. [CrossRef] [PubMed]

133. Liu, Y.; Kern, J.T.; Walker, J.R.; Johnson, J.A.; Schultz, P.G.; Luesch, H. A genomic screen for activators of the antioxidant response element. Proc. Natl. Acad. Sci. USA 2007, 104, 5205-5210. [CrossRef] [PubMed] 